2009

\title{
Influenza A(H1N1) and Pandemic Preparedness Under the Rule of International Law
}

Lawrence O. Gostin

Georgetown University Law Center, gostin@law.georgetown.edu

This paper can be downloaded free of charge from:

http://scholarship.law.georgetown.edu/ois_papers/28 


\title{
GEORGETOWN UNIVERSITY
}

\section{O’Neill Institute for National \& Global Health Law Scholarship}

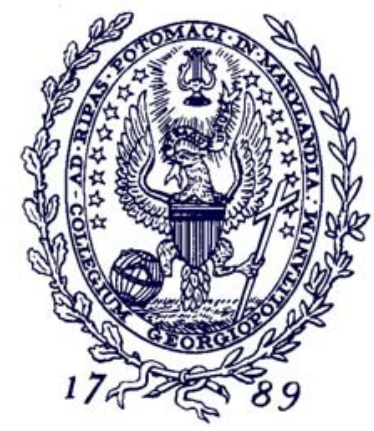

Research Paper No. 28

July 2009

\section{Influenza $\mathrm{A}(\mathrm{H} 1 \mathrm{~N} 1)$ and Pandemic Preparedness Under the Rule of International Law}

\author{
301 JAMA 2376 (2009) \\ Lawrence O. Gostin \\ The Linda D. and Timothy J. O’Neill Professor of Global Health Law \\ Georgetown Law \\ gostin@law.georgetown.edu
}

This paper can be downloaded without charge from:

http://ssrn.com/abstract $=1430929$

http://lsr.nellco.org/georgetown/ois/papers/28 
JAMA

Online article and related content current as of June 9, 2009.

\title{
Influenza A(H1N1) and Pandemic Preparedness Under the Rule of International Law
}

\author{
Lawrence O. Gostin
}

JAMA. 2009;301(22):2376-2378 (doi:10.1001/jama.2009.849)

http://jama.ama-assn.org/cgi/content/full/301/22/2376

Correction

Citations

Topic collections
Contact me if this article is corrected.

Contact me when this article is cited.

Viral Infections; Travel Medicine; Medical Practice; Law and Medicine; Public Health; World Health; Public Health, Other; Infectious Diseases

Contact me when new articles are published in these topic areas.
Subscribe

http://jama.com/subscribe

Permissions

permissions@ama-assn.org

http://pubs.ama-assn.org/misc/permissions.dtl
Email Alerts

http://jamaarchives.com/alerts

Reprints/E-prints

reprints@ama-assn.org 


\section{Influenza $\mathrm{A}(\mathrm{H} 1 \mathrm{~N} 1)$ and Pandemic Preparedness Under the Rule of International Law}

Lawrence O. Gostin, JD

A NOVEL STRAIN OF INFLUENZA A(H1N1) SPREAD RAPidly through Mexico in April 2009 and now spans the globe. By the time the World Health Orga nization (WHO) was notified and had responded, geographical containment was not feasible, leading the agency to call for mitigation. ${ }^{1}$ Early indications are that the first wave may not be as widespread or pathogenic as originally feared, but this influenza strain could evolve to become more dangerous in subsequent waves, as did the 1918 Spanish influenza that killed some 50 million individuals.

The international outbreak of severe acute respiratory syndrome (SARS) in 2003 and the more recent influenza $\mathrm{A}(\mathrm{H} 5 \mathrm{~N} 1)$ among birds with limited transmission to humans helped prepare the world for the current pandemic threat. SARS galvanized WHO to revise the antiquated International Health Regulations ${ }^{2}$ in 2005, which took effect June $15,2007 .{ }^{3}$ Governments instituted preparedness plans in response to avian influenza. ${ }^{4}$

Despite increased preparedness, WHO and the Centers for Disease Control and Prevention (CDC) lack key powers and resources. Reminiscent of past responses, many governments are acting out of fear or economic and political self-interest rather than out of scientific reason. Above all, there are serious questions of global justice, as Mexicans have become subject to stigma and discrimination.

\section{WHO Pandemic Alert System}

On April 29, WHO raised the pandemic alert level to 5, the second highest level. The World Health Assembly revised the pandemic alert level system in 2009, but that action has been ineffective because it does not trigger agency powers, and countries are not required to take any action. The alert system is based on geographic distribution of sustained spread among humans without due regard to the actual health threat because it could entail relatively mild disease. The threat level, moreover, could heighten fears and cause the public to overreact.

\section{International Health Regulations}

The revised International Health Regulations for the first time in history permits an organized global response within the rule of international law, and $\mathrm{H} 1 \mathrm{Nl}$ offers the first test of its effectiveness. The International Health Regulations' purpose is "to prevent, protect against, control and provide a public health response to the international spread of disease," while balancing the values of human rights and free trade (Article 2). ${ }^{2}$

Emergency Declaration. On April 25, 2009, the WHO director-general convened an emergency committee and declared a "public health emergency of international concern," marking the first time a declaration had been made under the new regulations, which define a public health emergency as an extraordinary event that constitutes a public health risk to other states through the international spread of disease, potentially requiring a coordinated international response.

Notification. In the early, crucial weeks of the SARS outbreak in 2003, China did not openly and promptly report the first SARS cases. Consequently, the International Health Regulations now require states to notify $\mathrm{WHO}$ of all events within their territories that may constitute a public health emergency. The WHO director-general, not the state, has the ultimate authority to determine whether an event is of international concern. More specifically, states must report any case involving a new subtype of human influenza. WHO has authority to bypass official state reporting and require countries to verify unofficial data sources and can harness new information technologies such as the Global Outbreak Alert and Response Network. The mandate to report and use additional data sources strengthens WHO's ability to track, analyze, and respond to emerging infectious diseases.

WHO Recommendations. A declaration triggers the director-general's power to issue temporary recommendations. The director-general may also issue standing recommendations on routine, periodic application of health measures for specific, ongoing public health risks. On the same day the director-general made her declaration, she recommended that "all countries should intensify surveillance for unusual outbreaks of influenza-like illness and severe pneumonia." ${ }^{5}$ The director-general did not recommend travel or trade restrictions, screenings, or examinations.

Human Rights. The International Health Regulations require states to treat travelers with respect for their dignity, human rights, and fundamental freedoms. Although the regulations allow countries to impose personal restrictions beyond those recommended by WHO, these may be no more

Author Affiliation: O'Neill Institute for National and Global Health Law, Georgetown University, Washington, DC.

Corresponding Author: Lawrence O. Gostin, JD, Georgetown University Law Center, 600 New Jersey Ave NW, Washington, DC 20001 (gostin@law.georgetown.edu).

(C)2009 American Medical Association. All rights reserved. 
restrictive, invasive, or intrusive than reasonably available and effective alternatives. Generally, states cannot require invasive medical examinations, vaccinations, or other prophylaxis as a condition of entry for travelers or require health documents beyond those permitted under the International Health Regulations.

International Trade. The International Health Regulations, consistent with World Trade Organization rules, require trade restrictions to be based on scientific evidence and risk assessments. Trade measures must be no more restrictive of international commercial traffic than reasonably available and effective alternatives.

\section{Gaps in WHO Powers and Resources}

The International Health Regulations, therefore, empower WHO to provide leadership on public health measures. Yet there remain significant gaps in the agency's authority and resources necessary for an effective global response.

Monitoring and Enforcement. Widespread failure to comply with international norms was a key reason for the new International Health Regulations. Yet the regulations afford WHO little authority to monitor and enforce rules. Although most countries conscientiously reported $\mathrm{H} 1 \mathrm{~N} 1$, WHO has no authority to penalize for a failure to notify. More importantly, the International Health Regulations impose binding limits on travel and trade restrictions, but many countries have flagrantly violated this norm with impunity. The WHO director-general has power to make recommendations, but the International Health Regulations explicitly state that those new recommendations are nonbinding.

Capacity Building. Perhaps the most important norm in the International Health Regulations is the requirement for countries to build capacities for surveillance and response. Yet low- and middle-income countries lack adequate public health infrastructures. Although the regulations encourage rich states to donate resources and technical assistance, precious little has been devoted to build capacity in poor countries. This places the world at significant risk because emerging infectious diseases often originate in highly populous countries in Africa and Asia with close interchange between humans and animals.

Virus Sharing. WHO has been embroiled in a major controversy with Indonesia for 2 years over its refusal to share influenza $\mathrm{A}(\mathrm{H} 5 \mathrm{N1})$ virus samples that are critically needed to assess the threat of novel strains of influenza. Indonesia, supported by many low-income countries, argues that it would not be guaranteed affordable and sufficient access to vaccines. The International Health Regulations do not afford WHO authority to resolve disputes like these, despite its importance to global security.

\section{Gaps in CDC Powers and Resources}

Most individuals believe that highly developed countries such as the United States have all the power and resources they need. Yet, the CDC and state and local health departments lack both.
Although all other major countries with federal systems signed the International Health Regulations without reservation, the United States gave notice that it might not comply with the regulations under principles of federalism if a public health power belonged to the states rather than to the federal government.

The Canadian SARS Commission criticized the lack of legal power and resources available to public health agencies. ${ }^{6}$ This resulted in fundamental reform of public health law and an influx of resources. The United States, however, has not learned those lessons. The CDC's legal authority to prevent the introduction, transmission, or spread of communicable diseases into or within the United States dates back to 1944, but its critical powers - to quarantine, inspect, disinfect, and destroy animals-have limited applicability to a few diseases. If the CDC tried to exercise power, its legal authority would be challenged, causing needless delays and uncertainty, and its actions might be ruled unconstitutional. To its credit, the CDC has tried for more than a decade to modernize its legal authority. But even though its proposed fundamental revision was submitted more than 3 years ago, regulations have yet to be finalized. ${ }^{7}$

Federal and state legislatures have also allocated inadequate resources to the CDC and state and local health departments. As the cost of health care has soared, only about $2.5 \%$ of total health spending has been allocated to prevention and public health. ${ }^{8} \mathrm{~A}$ few states have strong surveillance systems, but many others are deficient so that early warning and response are highly fragmented.

\section{Global Justice}

Despite the International Health Regulations norm that travel and trade must be scientifically well founded and respectful of human rights and commerce, countries have implemented numerous restrictions. Mexico has sustained severe economic and social repercussions as tourism and trade have sharply decreased; its gross national product declined $0.3 \%$ to $0.5 \%$ in a matter of weeks. ${ }^{9}$ The media refers to $\mathrm{H} 1 \mathrm{Nl}$ as the "Mexican" flu. Mexicans have been inappropriately blamed and called unclean, and conservative US commentators have urged tougher penalties against Mexican immigrants. ${ }^{10}$

Quarantine and Thermal Scanning. Asian countries previously affected by SARS have been most aggressive in response to H1N1, although all regions have adopted coercive measures. ${ }^{11}$ China and Hong Kong implemented quarantines for travelers from Mexico, Canada, and the United States. ${ }^{12}$ Furthermore, 22 Canadian university students with no apparent flu symptoms were held in a hotel in Changchun, a city in northeastern China. ${ }^{12}$ In Hong Kong, an infected man from an AeroMexico flight was isolated, while 300 guests and employees at the hotel where he stayed were confined for a week under police guard. ${ }^{13}$ In Singapore, anyone who recently visited Mexico was placed into home quarantine. Additionally, thermal scanners were set up at airports and hospital isolation units in China and Singapore, where staff at emergency departments wore full protective clothing. ${ }^{11}$

(Reprinted) JAMA, June 10, 2009—Vol 301, No. $22 \mathbf{2 3 7 7}$ 
Social Distancing. Social distancing measures have been widely adopted, including closure of schools, public events, and mass transportation. The CDC recommended school closures for up to 14 days if a case of H1N1 influenza was suspected or confirmed. Before the CDC reversed its position only 4 days later, more than 700 schools were closed, affecting some 245000 children. $^{14}$

Travel Restrictions. WHO suggested travel restrictions would have "very little effect on stopping the virus from spreading, but would be highly disruptive to the travel community." ${ }^{15}$ Despite this, many countries, including the United States, have advised against all nonessential travel to Mexico. Some countries have implemented outright travel bans. For example, China suspended all flights between the 2 countries and chartered a plane to pick up Chinese nationals within Mexico. Additionally, Latin American countries (Argentina, Peru, Ecuador, and Cuba) suspended flights from Mexico. Countries such as Japan and Singapore have singled out Mexicans for special visa requirements such as requiring a medical examination or only accepting mail applications to avoid physical contact.

Trade Restrictions and Culling. There is no scientific evidence that eating pork causes influenza. Yet 20 countries have banned meat from Mexico, Canada, and the United States, including 2 of the world's largest pork importers, China and Russia. In response, Mexico filed a statement with the World Trade Organization arguing that such bans violate international trade rules. Egypt took the drastic measure of culling the country's estimated 400000 pigs, perhaps motivated by prejudice against the Coptic Christian minority (the primary consumers of pork).

Epidemics often bring out irrational fears and discriminatory behaviors among individuals and governments. It is all the more important, therefore, to have an international system guided by science that has adequate funding for research and public health and that conforms to the rule of international law.

Financial Disclosures: None reported.

\section{REFERENCES}

1. Chan $M$. Influenza $A(H 1 N 1)$ [statement by WHO Director-General Dr Margaret Chan]. April 29, 2009. http://www.who.int/mediacentre/news/statements /2009/h1n1_20090429/en/index.html. Accessed May 7, 2009.

2. International Health Regulations (2005). 2nd ed. Geneva, Switzerland: World Health Organization; 2008. http://whqlibdoc.who.int/publications/2008 19789241580410_eng.pdf. Accessed May 18, 2009.

3. Fidler DP, Gostin LO. The new International Health Regulations: an historic development for international law and public health. J Law Med Ethics. 2006; 34(1):85-94.

4. Gostin LO. Medical countermeasures for pandemic influenza: ethics and the law. JAMA. 2006;295(5):554-557.

5. Chan M. Swine influenza [statement by WHO Director-General Dr Margaret Chan]. April 25, 2009. http://www.who.int/mediacentre/news/statements/2009 /h1n1 20090425/en/index.html. Accessed May 7, 2009.

6. Campbell C; SARS Commission. Second interim report: SARS and public health legislation. April 5, 2005. http://www.health.gov.on.ca/french/publicf/pubf /ministry_reportsf/campbell05f/campbell05.pdf. Accessed May 7, 2009.

7. Control of communicable diseases. Fed Regist. 2005;70(229):71892-71948. To be codified at 42 CFR parts 70 and 71 .

8. Beitsch LM, Brooks RG, Menachemi N, Libbey PM. Public health at center stage: new roles, old props. Health Aff (Millwood). 2006;25(4):911-922.

9. The butcher's bill: flu and the global economy. Economist. April 30, 2009

10. Washington J. Immigration foes use swine flu to renew arguments that Mexican border should be sealed. Los Angeles Times. May 2, 2009.

11. The world response to flu crisis. BBC News. May 5, 2009. http://news.bbc .co.uk/2/hi/americas/8022516.stm. Accessed May 5, 2009.

12. Oster $\mathrm{S}, \mathrm{Ho}$ PJ. China clashes with Canada as Mexicans depart. Wall Street Journal. May 6, 2009:A10.

13. Cheng J, Stein P. A room with a flu: dispatches from a Hong Kong hotel. Wall Street Journal. May 5, 2009:A1.

14. US Department of Education. H1N1 flu \& US schools: answers to frequently asked questions. http://www.ed.gov/admins/lead/safety/emergencyplan/pandemic /guidance/flu-faqs.pdf. Updated May 5, 2009. Accessed May 7, 2009.

15. World Health Organization. Epidemic and pandemic alert and response (EPR). Travel: is it safe to travel? http://www.who.int/csr/disease/swineflu /frequently_asked_questions/travel/en/index.html. Updated May 7, 2009. Accessed May 7, 2009.

\section{New Guidelines for the Management of HIV-Related Opportunistic Infections}

Henry Masur, MD

Jonathan E. Kaplan, MD

\section{$\mathrm{T}$} HE YEAR 2009 MARKS THE 21ST ANNIVERSARY OF THE first meeting to draft an AIDS management guideline for prophylaxis against Pneumocystis carinii pneumonia in persons with human immunodeficiency virus (HIV) infection. ${ }^{1}$ In 1988, knowledge about HIV/ AIDS was rapidly increasing, but relevant publications were appearing in a wide array of journals that clinicians could not easily track, and practitioners articulated a need to have a concise, reliable summary of "best practices."

The initial guidelines were developed by a group of experts from the major AIDS care centers in the United States, who reviewed the literature, debated the issues in a 2-day meeting, provided evidence-based recommendations, and promptly published their guidelines. ${ }^{1}$ Subsequently, these guidelines were broadened to include prevention and treatment of other opportunistic infections in HIV-infected adults and children. ${ }^{2-8}$ As clinicians and publishers became more comfortable using Web-based resources, these guidelines were posted on the Web with links from Web sites sponsored by the Centers for Disease Control and Prevention, the National Institutes of Health, and the Infectious Diseases Society of America

Author Affiliations: National Institutes of Health, Bethesda, Maryland (Dr Masur); and Centers for Disease Control and Prevention, Atlanta, Georgia (Dr Kaplan). Corresponding Author: Henry Masur, MD, National Institutes of Health Clinical Center, 10 Center Dr, Bldg 10, Room 2C145, National Institutes of Health, Bethesda, MD 20892 (hmasur@nih.gov). 